\title{
Research on the Fusion of Management Accounting and Financial Accounting
}

\author{
Ling Cheng \\ Institute of Technology, East China Jiaotong University, Nanchang, Jiangxi, 330024
}

Keywords: management accounting; financial accounting; fusion

\begin{abstract}
With the rapid development of China's economy, the contents and methods of accounting work are constantly changing. In order to meet the needs of social development, management accounting and financial accounting must be gradually integrated according to the company's operating conditions and the characteristics of accounting work. Therefore, this paper analyzes the integration of management accounting and financial accounting, and proposes a fusion strategy to promote the improvement of the management model of enterprises. Through effective financial analysis, it promotes enterprises to improve their management level and improve their business performance.
\end{abstract}

\section{Introduction}

The financial accounting of an enterprise generally provides financial information such as the financial status of the unit and the current status of the profit and loss for the relevant personnel of the company. Enterprise management accounting is mainly based on business management, mathematics statistics, information technology, operations planning and many other disciplines. Its definition refers to the unit's use of an efficient accounting model and conclusion evaluation system, the unit of a company's accounting review period The detailed calculations and audits are performed on the business results achieved within the company, and the production, operation, and capital use of the unit are dissected, so that the unit's operating behavior can be efficiently estimated, and the unit's decision-making, review, and review sections can be controlled to take advantage of these actions. To reasonably and correctly restrain and teach the business operations of enterprises, and significantly promote the operating profits of enterprises and institutions. Provide detailed and efficient decision support for future business operations. The management accounting promotion unit of an enterprise can understand the business situation of the company more thoughtfully, and the future business behavior of the initial unit is more purposeful; assisting the unit to effectively avoid risks, the stability of the operation after the initial operation is higher, and the harm is less; Providing reasonable advice on issues can increase the unit's competitiveness in the same industry [1].

\section{Different Points of Management Accounting and Financial Accounting}

The main content of management accounting is the analysis and evaluation of corporate funds, and the prediction and control of corporate capital risks; while financial accounting is mainly used to accurately calculate corporate assets, liabilities, income, expenditures, profits and other corporate liquidity, in the form of reports The operating status of the company provides information for decision makers.

Management accounting mainly provides valuable business management information and decision-making information to the enterprise, directly providing effective information basis for the internal management personnel [2] of the company, improving the efficiency of the internal management staff and ensuring the economic benefits of the enterprise. Financial accounting is to provide basic financial information to the outside of the company. It is for all interest groups that are in contact with the company. The service target can be individuals or groups.

The focus of management accounting is to provide services for the company's daily operations and management activities, regularly review and summarize past experience, and make estimates 
and decisions about the future development of the company. The focus of financial accounting is based on the past experience of information data, in the form of reports to accurately reflect the company's business activities.

There is a certain flexibility in the preparation of the work report for management accounting. According to the needs of business managers, it can be one day, several months, or several years. However, there are hard rules for the preparation of work reports for financial accounting. In general, the preparation of work reports for financial accounting is one quarter, or one year.

\section{Possibility of Fusion of Management Accounting and Financial Accounting}

Management accounting and financial financial accounting are generally important components of the accounting system of enterprises and institutions. Their goals are all effective control units and promote the stable development of the unit. The enterprise's accounting behavior is a part of the unit management system, so the unit's management accounting and financial accounting belong to the scope of unit management behavior, and all have the management function of the unit. However, based on the development of China's current accounting base, it is even later than abroad. Most of the accounting units of the company have stagnated at the audit level of financial accounting, and have not yet developed a relatively good management accounting system for enterprises and institutions. The management accounting and financial accounting of enterprises and institutions are all included in the discipline of management economics. The combination of the two has a very solid theoretical basis.

The enterprise's financial accounting exercises budgets and audits on the capital generated in the unit production and operation activities. The relatively easy-to-use costs in the auditing unit's business activities are consistent with the specific targets adopted in the unit price budget process. If there is a large difference between the two, Differently, you need to find specific reasons and implement effective regulation [3]. The management accounting of an enterprise generally reviews and assesses the control of the constituent members' profits, unit cost control, and unit budgetary actions of the unit. Therefore, corporate management accounting and financial accounting both have two basic functions of control and review. The objects of control and review of both are the operational status of the unit. It is only the point that the two pay attention to. The financial accounting of enterprises and institutions Indirectly controlling and supervising the production and operation of enterprises, the management accounting of enterprises and institutions is generally higher than financial accounting. It is the use of the company's financial accounting data to conduct further discussion and control. The management accounting of enterprises is the thinking and operation of financial accounting. continued.

\section{Strategy for the Integration of Management Accounting and Financial Accounting}

The development level of management accounting in Chinese enterprises is relatively low, and the development speed is slow. Most enterprises do not have a specific regulation and control accounting unit, and there is a relative shortage of scientific and technical talents in management accounting. The financial accounting of enterprises is also a key basic operation for maintaining the business continuity of enterprises. Through these financial and accounting review procedures, paper-based financial statements with a higher quality and higher reliability number are issued to debtors, shareholders, institutions, and other departments. The financial details of the promulgating unit ensure the interests of the designer of the unit, maintain the stable and sustainable development of the market economy in China, provide practical financial information for the managers of the company, assist the unit in improving economic interests, and achieve the purpose of profit growth. Therefore, the company's financial accounting that can also be called foreign-related financial reporting accounting [4]. The unit should set up a dedicated management accounting department, and then set up a training mechanism for management accounting technical personnel. With the aid of daily education and training, the professional skills of the technicians should be improved so that the technicians not only possess professional knowledge of accounting theory, but also can master 
the mastery. The knowledge of financial regulation can provide ample impetus for the long-term development of the company.

Estimating management is one of the important functions of a unit's financial institution. It should strengthen the close cooperation between corporate management accounting and financial accounting. The reason is that the enterprise's estimation management process belongs to the scope of management accounting, and it depends on the quality of the company's financial accounting work. Both of them coordinate and promote each other in the enterprise's estimation management work, and together implement the enterprise's estimation management operation. The financial accounting level analyzes the operating status data of the unit and faithfully reflects the operating status of the unit and generates paper financial statements. The enterprise's management accounting implements specific inspection and supervision of the management within a certain unit of a unit. The initial data and news source of the operating profits adopted by the management accounting of enterprises and institutions are the statistical results of the financial accounting of the company. This requires companies to implement the system's estimated management of the unit's management accounting ideas in financial accounting operations. Enterprises need to formulate system production and operation standards and budget production and operation costs at the beginning of the year, perform performance evaluation and review in each production cycle, and determine rewards and punishments through performance. The preparation of data sheets and audits for the company's operating cost consumption needs to be carried out according to the production month, and an analysis of variance is performed between the estimated coefficients to find the root cause of the cost exceeding the budget, and lay a good foundation for future cost and cost control.

The financial accounting and management accounting of an enterprise come from the same information source. Most of the current enterprises and institutions completely separate the financial accounting and management accounting of the enterprise. There is not much connection between the two, resulting in repeated operations of the enterprise and the resulting enterprise. The operating costs increase. However, the resumes share the original data of the two accounting methods, creating an information sharing platform for both. Under the new economic situation, the organizational forms of individual enterprises and institutions are transformed into information organizations, such as industrial clusters, accounting information globalization, and network information, as well as various types of information network institutions related to this, and will be in an information-based perspective. Management chain management mechanism is added to the management system of enterprises and institutions[5]. These new organizational forms must be matched with the matching management system and method system to play a more active role. Not only save manpower and material resources, promote the efficiency of accounting work, improve the level of information technology within the unit, use information sharing system to promote the integration of enterprise management accounting and financial accounting, promote the change of the authority of the financial department of the company, change from the review to the decision, The unit's audit function is separated from the financial department, prompting the company's financial accounting and management accounting to perform their duties and perform their own functions.

Accounting work needs to face and deal with large and complex financial data, and the integration of financial accounting and management accounting needs to achieve data sharing. Modern information technology provides technical support for data sharing, and can also perform remote control and implementation management, improve data. The efficiency of processing. First of all, the enterprise must code and classify the data of financial accounting and management accounting, and organize the information catalog for easy reference and management. Secondly, according to the information catalog component database management system, the financial accounting and management accounting information should be unified and integrated to achieve data sharing. Finally, link the database with the enterprise ERP system to achieve efficient sharing of information within the company, to facilitate management personnel to master the operation of the enterprise. The integration of financial accounting and management accounting requires companies to have a deep understanding of the relationship and the differences between the two. 
Through the analysis of the functions and characteristics of the two, it discusses effective methods for mutual integration. This process needs gradual progress and cannot be quick and immediate. First of all, the integration of the two needs to ensure that the current accounting system can continue to play its role as a precondition, so that the accounting work of the company does not appear chaotic; Second, to strengthen the management accounting system to improve and narrow the gap with the financial accounting; Finally, the enterprise Must pay attention to each integration link, find problems and adjust them in time.

\section{Conclusion}

The integration of management accounting and financial accounting has become the focus of corporate development. In order to give full play to the functions of management accounting and financial accounting, we must increase the efforts to cultivate high-quality accounting personnel, establish and improve relevant rules and regulations, and establish specialized management accounting. Departments, making full use of advanced computer technology, through the establishment of a sound accounting work system to promote the healthy and efficient development of enterprises, improve the company's overall market competitiveness.

\section{References}

[1] Li Na. Analysis of the Integration of Management Accounting and Financial Accounting [J]. Global Market Information, 2014, 12(22):201-206.

[2] Cheng Yan. The Fusion of Financial Accounting and Management Accounting in the New Situation [J]. Accounting Research, 2011(2): 52-54.

[3] Liang Yuan. Discussion on the Integration of Financial Accounting and Management Accounting in the New Situation [J]. New Economy, 2016(21): 77.

[4] Yang Hong, Liu Jiaxin. The only way to perfect China's accounting system: the integration of financial accounting and management accounting [J]. JIANGSU COMMERCIAL, 2013 (36): 255-256.

[5] Wang Jiachang, Wang Bing. Innovative Thinking of Accounting Report Improvement: Concurrently Discussing the Fusion of Financial Accounting Report and Management Accounting Report [J]. Economic Management, 2003(9): 44-47.

[6] Zhang Shuo, Zhang Junmin. The Fusion of Management Accounting and Financial Accounting: An Analysis Based on R\&D Expenditure and Sunk Cost [J]. Finance and Accounting, 2016(7): 66-67. 